\title{
KARAKTERISTIK MORFOLOGI DAN KIMIAWI BEBERAPA VARIETAS UBI KAYU MANIS ASAL KECAMATAN PALAS, KABUPATEN LAMPUNG SELATAN BERDASARKAN UMUR PANEN YANG BERBEDA \\ Morphology and Chemical Characteristics of Some Cassava Types Grown in South Lampung Based on Different Age of Harvest
}

\author{
Siti Nurdjanah ${ }^{1) *}$, Susilawati Susilawati ${ }^{1)}$, Udin Hasanudin ${ }^{1)}$, Ayu Anitasari ${ }^{1)}$ \\ ${ }^{1)}$ Jurusan Teknologi Hasil Pertanian, Fakultas Pertanian, Universitas Lampung \\ Jalan Prof. Dr. Ir. Sumantri Brojonegoro No. 1, Bandar Lampung, Lampung, 35145 \\ *Korespondensi Penulis: siti.nurdjanah@fp.unila.ac.id
}

\begin{abstract}
Most of cassava grown in Palas, South Lampung District is sweet type cassava (Manihot esculenta Crantz) utilized as raw materials for cassava-based snack production. However, their characteristic had never been reported. The aims of the research were to determine the effect of varieties, harvesting age, and interaction between varieties and the harvesting age on morphology and chemical characteristics of sweet type cassava planted in Palas District, South Lampung. The experiment was factorial and arranged in a Complete Randomized Block Design (CRBD) with two factors and four replications. The first factor was cassava variety, i.e., manalagi (V1), mentega (V2), and krembi (V3). The second factor was the harvest age (U) i.e., 7-8 months (U1) and 8-9 months (U2). Morphology data were reported descriptively, while data for other characteristics were tested for homogeneity and additivity using Barlett and Tuckey test, then subjected to ANOVA, and further tested using Duncan test at the level of 5\%. The results showed that the variety and harvest age significantly affected of water content, starch yield, starch content, amylose, and amylopectin. There was a significant interaction between varieties and age of harvest on moisture content, starch yield, and starch content, but there was no significant interaction effect on amylose and amylopectin. The highest value of moisture content was found in manalagi aged at 7-8 months $(67.28 \% \mathrm{wb})$, the highest value of starch yield was found in manalagi age at 8-9 months of (16.34\%), the highest value of starch content was found in mentega aged at 8-9 of months (17.52 \% wb), the highest value of amylose was found in mentega aged at $8-9$ of month $(10.35 \% \mathrm{db})$, the highest value of amylopectin was found in krembi aged at 7-8 of month $(92.78 \% \mathrm{db})$. Overall, krembi, manalagi, and mentega can be categorized as lowamylose cassava which has potential to be developed as raw material for crispy cassava-based snack.
\end{abstract}

Keywords: harvesting age, krembi, low-amylose cassava, manalagi, mentega

\section{PENDAHULUAN}

Ubi kayu (Manihot esculenta Crantz) atau dikenal sebagai ketela pohon dapat tumbuh hampir di semua daerah dan menjadi salah satu tanaman pokok selain padi dan jagung. Ubi kayu di Provinsi Lampung memiliki produktivitas tinggi. Menurut luas panen ubi kayu di Indonesia tahun 2019 seluas 0,63 juta hektar dengan produksi 16,35 juta ton (Sinar Tani, 2020). Lampung Selatan merupakan salah satu wilayah yang memiliki potensi ubi kayu dengan luas lahan panen sebesar 9.718 ha dengan produksi 210.175 ton. Palas merupakan salah satu Kecamatan yang berada di Kabupaten Lampung Selatan yang memiliki luas panen tanaman ubi kayu sebesar 16 ha dengan produksi 377 ton (Dinas TPH dan Perkebunan Kabupaten Lampung Selatan (2017)). Ubi kayu yang ditanam di Kecamatan Palas sebagian besar ubi kayu jenis manis, yang juga disebut ubi konsumsi. Ubi kayu jenis manis adalah ubi kayu yang dapat dikonsumsi setelah mengalami pengolahan dengan kadar $\mathrm{HCN}$ rendah sebesar $0,04 \%$ atau $40 \mathrm{mg} \mathrm{HCN} / \mathrm{kg}$ ubi kayu (Ginting, 2002; Yuningsih, 2009). Beberapa varietas ubi kayu jenis manis 
yang berada di Kecamatan Palas meliputi ubi kayu manalagi, mentega, dan krembi. Petani di Kecamatan Palas umumnya memanfaatkan ketiga varietas tersebut pada umur panen 7-9 bulan untuk pengolahan makanan berupa keripik, kelanting, dan tape. Namun ubi kayu varietas tersebut hingga saat ini belum pernah didata secara rinci tentang morfologi dan kandungan kimianya.

Sifat fisikokimia ubi kayu dapat dipengaruhi oleh varietas dan umur panen (Moorthy, 2002). Ubi kayu memiliki waktu pemanenan yang berbeda-beda setiap varietasnya (Rubatzky \& Yamaguchi, 1998). Perbedaan umur panen akan menghasilkan sifat fisiko-kimia ubi kayu yang berbeda. Menurut Wang et al. (2010) umur panen, varietas dan kondisi pascapanen akan menghasilkan sifat fisikokimia yang berbeda. Perbedaan karakteristik fisiko-kimia dari bahan akan menyebabkan perbedaan sifat fungsionalnya (Copelan et al., 2009; Nwokocha et al., 2012).

Sifat fungsional adalah bagaimana suatu bahan mengalami perubahan secara fisik dan kimia selama persiapan dan pemasakan sehingga mempengaruhi sifat produk akhir. Perbedaan sifat fungsional disebabkan oleh perbedaan sifat kimia maupun sifat fisik, seperti ukuran granula pati yang dianalisis menggunakan scanning electron microscope (SEM), dan warna yang dideteksi meggunakan color difference meter (CDM). Hal tersebut diakibatkan oleh perbedaan varietas dan umur panen sehingga dapat menghasilkan ketidak-konsistenan kualitas bahan baku. Kualitas bahan baku yang tidak konsisten akan berdampak pada perbedaan kualitas produk akhir yang dihasilkan (data belum dipublikasi). Sifat fisik dan kimia ubi kayu perlu diketahui karena sifat fisiko-kimia sangat penting dalam pengolahan makanan (Syamsir et al., 2011). Oleh karena itu perlu dilakukan kajian tentang pengaruh varietas dan umur panen terhadap karakteristik seperti sifat morfologi dan sifat kimiawi ubi kayu manis varietas manalagi, mentega dan krembi.

\section{METODE PENELITIAN}

\section{Alat dan Bahan}

Alat-alat utama yang digunakan adalah blender merek Phillips, oven merk Memmert, desikator, timbangan digital Merk Shimadzu, Erlenmeyer merk Pyrex $250 \mathrm{~mL}$, Soxhlet dan mikro Kjeldahl aparatus, spektrofotometer UV-Vis merk Genesys 10S Thermo Scientific. Bahan yang digunakan adalah ubi kayu (Manihot esculenta Crantz) segar varietas mentega, manalagi dan krembi dengan umur 7-8 bulan dan 8-9 bulan yang dipanen dari Kecamatan Palas, Kabupaten Lampung Selatan, akuades, $\mathrm{H}_{2} \mathrm{SO}_{4}, \mathrm{NaOH}, \mathrm{HCl}$, kertas saring, etanol, asam asetat, larutan iod, enzim $\alpha$-amilase, enzim $\alpha$ glukoamilase, $\mathrm{AgNO}_{3}, \mathrm{HNO}_{3}$, K-tiosianat, amilosa murni, dan indikator ferri.

\section{Tahapan Penelitian}

Ubi kayu dipanen pada rentang umur yaitu 7-8 dan 8-9 bulan pada hari yang sama. Ubi kayu tersebut adalah ubi kayu manis varietas manalagi, mentega, dan krembi yang ditanam di lokasi perkebunan Kecamatan Palas, Kabupaten Lampung Selatan.

\section{Rancangan Percobaan}

Penelitian ini menggunakan metode rancangan acak kelompok lengkap (RAKL) faktorial 2 faktor dan 4 kali ulangan. Faktor I terdiri dari 3 taraf dan faktor II terdiri dari 2 taraf. Faktor pertama merupakan varietas ubi kayu (V) yaitu manalagi (V1), mentega (V2) dan krembi (V3). Faktor kedua merupakan umur panen (U) yang terdiri dari 2 taraf yaitu taraf 7-8 bulan (U1) dan taraf 8-9 bulan (U2).

Data morfologi disajikan dalam bentuk deskriptif sedangkan data kandungan kimia diuji kesamaan ragamnya dengan uji Bartlett dan aditivitas model diuji dengan uji Tuckey. Analisis sidik 
ragam digunakan untuk mendapatkan penduga ragam galat dan uji signifikan untuk mengetahui pengaruh perlakuan, kemudian diolah lebih lanjut dengan uji Beda Nyata Duncan pada taraf $5 \%$.

\section{Metode Analisis}

Variabel yang diamati untuk karakter morfologi ubi kayu manis berupa warna pada pucuk daun dan daun dewasa, panjang lobus daun, warna dan panjang tangkai daun, warna batang, warna umbi, warna daun muda, warna daun dewasa, pigmentasi tangkai daun, warna kulit umbi, dan warna daging umbi. Data mengenai karakter morfologi ubi kayu diperoleh secara manual dengan pengamatan langsung secara visual dan pengukuran dimensi secara manual menggunakan penggaris, kemudian disajikan secara deskriptif.

Analisis kandungan kimiawi ubi kayu segar meliputi kadar air (AOAC 925.09., 2005), kadar HCN (AOAC, 1984), kadar pati ubi kayu menggunakan metode hidrolisis enzim, dilanjutkan dengan kuantifikasi gula menggunakan metode fenol asam sulfat (DuBois et al., 1956). Selanjutnya kadar pati dihitung dengan rumus $0,9 \times$ kadar gula, kadar rendemen pati berdasarkan Nurdjanah et al. (2008), kadar amilosa berdasarkan Aliawati, 2003), amilopektin dengan metode pengurangan dengan kadar amilosa pada kadar pati (100\%).

Preparasi sampel pada pengujian kadar air, HCN dan rendemen pati dilakukan segera setelah ubi kayu dipanen dan ditransportasikan ke laboratorium. Penentuan variabel lainnya dilakukan setelah ubi kayu utuh, bebas dari luka atau lecet, dicuci sampai bebas kotoran menggunakan air mengalir, disimpan pada suhu $20^{\circ} \mathrm{C}$, RH $90 \%$ selama 24 jam. Penyimpanan ini dilakukan karena keterbatasan kemampuan menganalisis sampel pada hari yang sama. Ubi kayu yang akan dianalisis, dikupas dan dicuci lagi sampai tidak ada kotoran yang menempel, kemudian dihancurkan menggunakan blender tanpa penambahan air.

\section{HASIL DAN PEMBAHASAN}

\section{Karakteristik Morfologi Ubi Kayu Manis}

Ubi kayu memiliki banyak varietas dan setiap varietas memiliki morfologi yang berbeda-beda. Morfologi ubi kayu diperlukan untuk mengetahui ciri-ciri visual yang tampak dari tanaman ubi kayu, sehingga dapat digunakan untuk membedakan varietas satu dengan lainnya, serta dapat digunakan untuk memperkirakan kandungan kimianya. Sebagai contoh warna umbi kuning atau kekuningan mengandung $\beta$-karoten yang lebih tinggi (data belum dipublikasi). Karakteristik morfologi yang diperoleh dari tanaman ubi kayu yang berada di Kabupaten Palas, Kabupaten Lampung Selatan berupa ubi kayu varietas manalagi, mentega dan krembi ditunjukkan pada Tabel 1.

Warna daun muda (pucuk) ketiga varietas umbi menunjukkan perbedaan yaitu hijau muda, hijau tua dan merah keunguan masing-masing untuk manalagi, mentega dan krembi. Akan tetapi warna daun setelah tua berubah menjadi hijau terang untuk manalagi dan mentega, sedangkan untuk krembi daun tua berubah menjadi hijau gelap. Selain mengandung klorofil, daun ubi kayu juga dilaporkan mengandung berbagai komponen polifenol yang berpotensi dijadikan sumber pangan fungsional (Laya \& Koubala, 2020)

Perbedaan lain yang dominan adalah warna umbi yaitu putih untuk manalagi dan krembi, warna kuning untuk mentega. Warna kuning ini mengindikasikan kandungan $\beta$-karoten pada umbi ubi kayu mentega. Umbi ubi kayu berwarna kuning memiliki potensi dikembangkan sebagai sumber kandungan $\beta$-karoten sekaligus juga untuk bahan pewarna makanan (Ayetigbo et al., 2018). 
Tabel 1. Karakteristik morfologi tiga varietas ubi kayu manis asal Kecamatan Palas, Kabupaten Lampung Selatan berdasarkan umur panen yang berbeda

\begin{tabular}{|c|c|c|c|}
\hline \multirow[b]{2}{*}{ Karakteristik } & \multicolumn{3}{|c|}{ Varietas } \\
\hline & Manalagi & Mentega & Krembi \\
\hline \multicolumn{4}{|l|}{ Pucuk daun } \\
\hline & Berwarna hijau muda & Berwarna hijau tua & Berwarna merah keunguan \\
\hline \multicolumn{4}{|l|}{ Daun dewasa } \\
\hline & $\begin{array}{c}\text { Berwarna hijau terang } \\
\text { dengan panjang lobus } \pm 22 \\
\mathrm{~cm} \text { dan lebar lobus } \pm 6,5 \mathrm{~cm}\end{array}$ & $\begin{array}{c}\text { Berwarna hijau terang } \\
\text { dengan panjang lobus } \pm 25 \\
\mathrm{~cm} \text { dan lebar lobus } \pm 6 \mathrm{~cm}\end{array}$ & $\begin{array}{c}\text { Berwarna hijau gelap } \\
\text { dengan panjang lobus } \pm \\
23,5 \mathrm{~cm} \text { dan lebar lobus } \pm \\
5,5 \mathrm{~cm}\end{array}$ \\
\hline \multirow[t]{2}{*}{$\begin{array}{l}\text { Tangkai } \\
\text { daun }\end{array}$} & & & \\
\hline & $\begin{array}{c}\text { Berwarna hijau kekuningan } \\
\text { dengan panjang } \pm 30 \mathrm{~cm}\end{array}$ & $\begin{array}{l}\text { Berwarna merah dengan } \\
\text { panjang } \pm 32 \mathrm{~cm}\end{array}$ & $\begin{array}{l}\text { Berwarna ungu dengan } \\
\text { panjang } \pm 33 \mathrm{~cm}\end{array}$ \\
\hline \multicolumn{4}{|l|}{ Batang } \\
\hline & $\begin{array}{l}\text { Berwarna hijau tua dan } \\
\text { dapat membentuk cabang } \\
\text { di bagian atas }\end{array}$ & $\begin{array}{l}\text { Berwarna abu-abu dan } \\
\text { tidak dapat membentuk } \\
\text { cabang di bagian atas }\end{array}$ & $\begin{array}{l}\text { Berwarna coklat gelap dan } \\
\text { tidak dapat membentuk } \\
\text { cabang di bagian atas }\end{array}$ \\
\hline \multicolumn{4}{|l|}{ Daging umbi } \\
\hline & Warna daging umbi putih & Warna daging umbi kuning & Warna daging umbi putih \\
\hline
\end{tabular}

\section{Karakteritik Kimiawi Ubi Kayu}

\section{Kadar Air Ubi Kayu Manis}

Umur panen dan varietas ubi kayu berpengaruh sangat nyata terhadap kadar air. Gambar 1 menunjukkan kadar air pada tiga varietas ubi kayu yaitu manalagi, mentega dan krembi. Ubi kayu dengan umur panen yang berbeda akan memiliki kadar air yang berbeda. Perbedaan kadar air setiap varietas disebabkan oleh genetika setiap tanaman dalam penyerapan air pada ubi kayu tersebut (Nugraha et al., 2015).
Ubi kayu yang memiliki kadar air tertinggi terdapat pada ubi kayu manalagi umur panen 7-8 bulan sebesar 67,27\%. Ubi kayu yang memiliki kadar air terendah terdapat pada ubi kayu krembi umur panen 8-9 bulan sebesar $62,12 \%$. Semua varietas ubi kayu (manalagi, mentega dan krembi) pada umur panen 7-8 bulan memiliki kadar air yang lebih tinggi dibandingkan dengan umur panen 8-9 bulan. Hal ini disebabkan oleh granula pati dan komponen-komponen non-pati lain yang terdapat di ubi kayu semakin bertambah, sehingga 
menyebabkan kadar air ubi kayu semakin menurun. Hal ini sesuai dengan penelitian Susilawati et al. (2008), bahwa ubi kayu Kasetsart yang ditanam pada kondisi tanah berbeda dengan umur panen 7-10 bulan menunjukkan bahwa semakin tua umur panen maka kandungan air pada ubi kayu semakin menurun, baik untuk ubi kayu yang ditanam di lokasi dengan tanah lempung berpasir halus maupun ubi kayu yang ditanam di tanah lempung berpasir sedang.

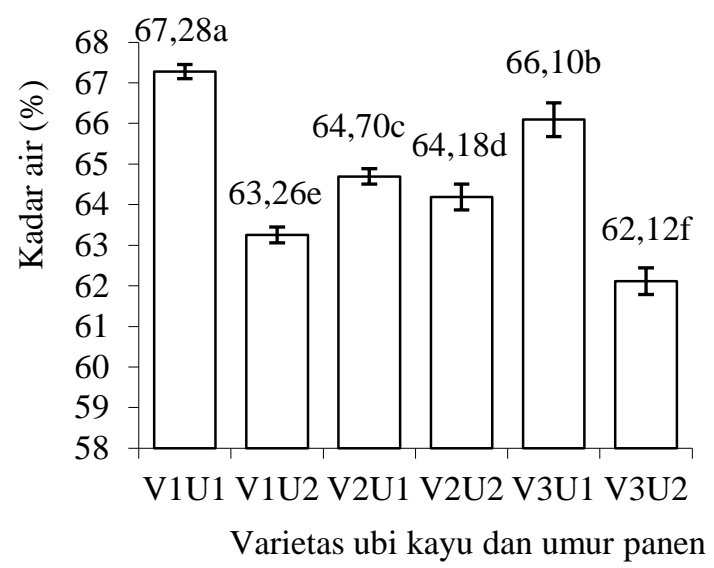

Gambar 1. Kadar air ubi kayu varietas manalagi (V1), mentega (V2), krembi (V3) dan umur panen 7-8 bulan (U1), 8-9 bulan (U2)

*)Keterangan: notasi yang berbeda menunjukkan adanya beda nyata pada $\alpha=5 \%$

\section{Kadar HCN Ubi Kayu Manis}

Ubi kayu manalagi yang dipanen dari Kecamatan Palas memiliki kadar $\mathrm{HCN}$ sebesar 21,2-23,6 ppm. Hasil tersebut lebih tinggi dibandingkan dengan penelitian Roja (2009), yang melaporkan bahwa ubi kayu manalagi dengan umur panen 7-10 bulan memiliki kadar HCN 19,5 ppm. Ubi kayu mentega yang berada di Kecamatan Palas dengan umur panen 7-9 bulan memiliki kadar HCN sebesar 27,7 ppm. Hasil tersebut lebih rendah dibandingkan kandungan $\mathrm{HCN}$ ubi kayu mentega yang dilaporkan oleh Ginting (2002) dan Yuningsih (2009) yaitu sebesar 40 ppm. Ubi kayu krembi yang berada di Kecamatan Palas dengan umur panen 7-9 bulan memiliki kadar HCN sebesar 21 ppm (Tabel 2). Hasil tersebut sesuai dengan hasil penelitian yang dilakukan Soetanto (2001), bahwa ubi kayu segar memiliki kadar HCN terendah sebesar 20 ppm. Semua varietas ubi kayu dengan umur panen 7-8 bulan dan 8-9 bulan di Kecamatan Palas memiliki kadar $\mathrm{HCN}$ kurang dari 40 ppm. Prabawati (2011) menyatakan bahwa ubi kayu manis merupakan ubi kayu dengan kadar $\mathrm{HCN}$ kurang dari 40 ppm sehingga aman untuk dikosumsi.

Tabel 2. Kadar HCN ubi kayu manis varietas manalagi, mentega dan krembi

\begin{tabular}{lc}
\hline $\begin{array}{l}\text { Perlakuan } \\
\text { (Varietas ubi kayu) }\end{array}$ & $\begin{array}{c}\text { Kadar HCN } \\
\text { (ppm) }\end{array}$ \\
\hline Manalagi (7-8 bulan) (V1U1) & $23,6 \mathrm{~b}$ \\
Manalagi (8-9 bulan) (V1U2) & $21,3 \mathrm{c}$ \\
Mentega (7-8 bulan) (V2U1) & $27,7 \mathrm{a}$ \\
Mentega (8-9 bulan) (V2U2) & $27,7 \mathrm{a}$ \\
Krembi (7-8 bulan) (V3U1) & $21,5 \mathrm{c}$ \\
Krembi (8-9 bulan) (V3U2) & $21,4 \mathrm{c}$ \\
\hline
\end{tabular}

Keterangan: notasi yang berbeda menunjukkan adanya beda nyata pada $\alpha=5 \%$

\section{Rendemen Pati Ubi Kayu Manis}

Hasil uji lanjut Duncan dengan taraf 5\% (Gambar 2) menunjukkan bahwa terdapat interaksi yang nyata antara varietas ubi kayu dan umur panen terhadap rendemen pati. Perbedaan banyaknya rendemen setiap varietas disebabkan oleh genetika setiap tanaman ubi kayu tersebut (Nugraha et al., 2015). Ubi kayu dengan umur panen 8-9 bulan memiliki kadar rendemen pati tertinggi terdapat pada ubi kayu manalagi dan terendah pada ubi kayu krembi. Rendemen pati yang dihasilkan pada ubi kayu mentega Kecamatan Palas lebih kecil (14,75-15,85\%) dengan umur panen 7-9 bulan dibandingkan dengan penelitian Nurhasan \& Pramudyanto (1996) yang memiliki rendemen pati sebesar $19 \%$. Rendemen pati ubi kayu manalagi memiliki kadar rendemen pati sebesar 12,39-16,34\% dengan umur panen 7-9 bulan. Ubi kayu krembi memiliki rendemen pati sebesar 
(10,07-14,86\%) dengan umur panen 7-9 bulan. Menurut Chairu \& Sofnie (2006) turunnya rendemen pati tersebut disebabkan oleh hilangnya pati saat pemisahan pati dari slurry pada tahap ekstraksi pati. Hal ini disebabkan oleh masih terikatnya sebagian pati pada onggok. Besarnya persen randemen ini juga dapat dipengaruhi oleh adanya proses penghancuran ubi kayu menjadi bubur/suspensi berisi pati dan komponen dinding sel. Proses pengecilan ukuran atau penghancuran menyebabkan partikelpartikel yang terbentuk akan semakin kecil dan terjadi penambahan kecepatan perputaran (sentrifugal) dari alat penghancur, sehingga pati akan lebih cepat mengendap.

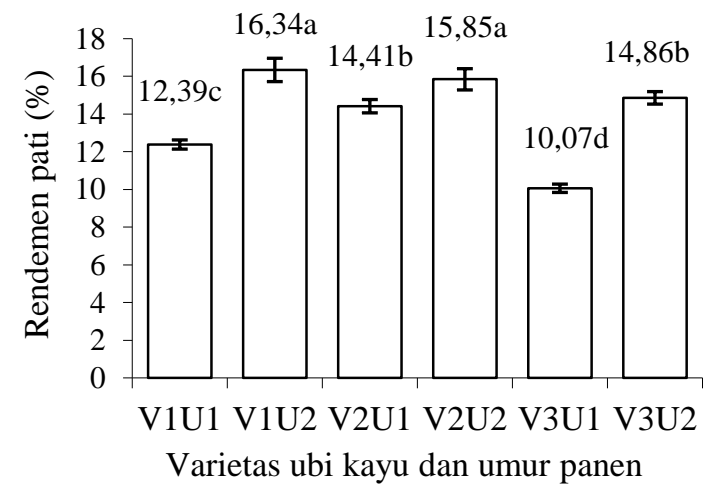

Gambar 2. Rendemen pati berdasarkan varietas ubi kayu yaitu manalagi (V1), mentega (V2), krembi (V3) dan umur panen 7-8 bulan (U1), 8-9 bulan (U2)

*)Keterangan: notasi yang berbeda menunjukkan adanya beda nyata pada $\alpha=5 \%$

\section{Kadar Pati Ubi Kayu Manis}

Kadar pati dipengaruhi secara sangat nyata oleh umur panen, varietas ubi kayu dan interaksi antara kedua faktor. Hasil uji lanjut Duncan dengan taraf 5\% bahwa setiap varietas ubi kayu (manalagi, mentega, dan krembi) memiliki persentase kadar pati yang berbeda. Hal ini diduga bahwa setiap varietas memiliki genetik yang tidak sama, sehingga akan mempengaruhi sintesis pati. Proses sintesis pati pada ubi kayu terjadi di kloroplas atau amiloplas. Komponen dasar granula pati terdiri dari dua poliglukan, yaitu amilosa dan amilopektin. Struktur molekul amilosa relatif sederhana, terdiri dari glukosa residu dihubungkan melalui ikatan $\alpha-(1,4)$ ke rantai panjang dengan beberapa cabang $\alpha$ $(1,6)$. Amilopektin adalah komponen utama, memiliki struktur dasar yang sama, tetapi memiliki rantai yang jauh lebih pendek dan banyak memiliki rantai bercabang $\alpha-(1,6) \quad$ (Bertoft, 2017). Pembentukan pati terjadi melalui glukosa1-fosfat di kloroplas dan plastid dengan ATP melalui bantuan enzim AGPase (EC:2.7.7.27) akan tebentuk ADP-Glukosa dengan pyrofosfat. Kemudian ADPGlukosa disintesis menjadi ADP dengan bantuan enzim starch syntases (EC: 2.4.1.21 dan EC:2.4.1.242). Pada awal pertumbuhan sintesis amilopektin akan lebih tinggi dibandingkan dengan amilosa, namun selama penuaan ubi kayu kedua polimer baik amilosa dan amilopektin disintesis secara simultan. Molekul amilopektin disintesis dari ADP dengan menggunakan enzim kompleks berupa enzim starch-branching enzyme (EC: 2.4.1.18), sedangkan molekul amilosa disintesis oleh GBSS (Granule-Bound Starch Synthase) yang terdapat pada molekul amilopektin dengan bantuan enzim de-branching enzymes (EC: 3.2.1.68) (Mitsui et al., 2010; Bull et al., 2018).

Ubi kayu umur panen 7-8 bulan memiliki kadar pati yang lebih rendah dibandingkan umur panen 8-9 bulan (Gambar 3). Tinggi dan rendahnya kadar pati diduga disebabkan oleh kecepatan sintesis pati pada ubi kayu yang berbeda setiap varietasnya dengan umur panen tertentu. Hal ini sesuai dengan penelitian $\mathrm{Li}$ et al. (2016) bahwa varietas F01 pada masa pembesaran pati $(180 \pm 5$ hari setelah tanam/HST) memiliki aktivitas AGPase yang lebih reaktif dalam mendegradasi glukosa1-fosfat menjadi ADP-Glukosa dibandingkan pada varietas $\mathrm{H} 124$, namun pada umur ( $240 \pm 5$ HST) aktivitas AGPase menurun pada varietas F01 dan varietas H124 meningkat. Hal ini membuktikan 
bahwa setiap varietas memiliki waktu atau umur tanam yang berbeda dalam pembentukan pati.

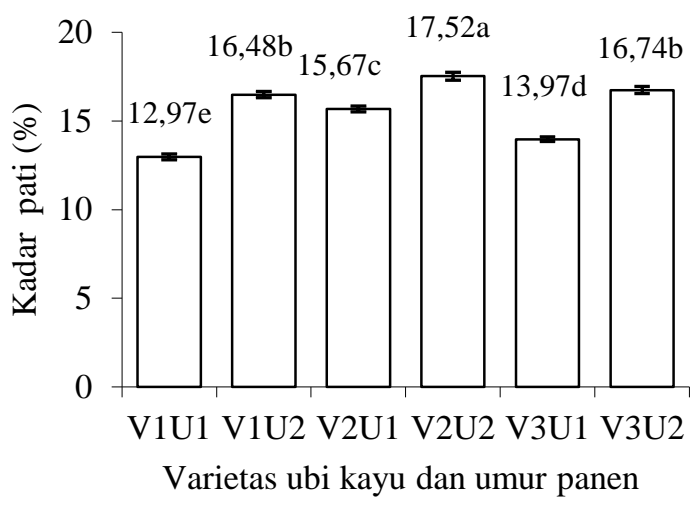

Gambar 3. Kadar pati berdasarkan varietas ubi kayu yaitu manalagi (V1), mentega (V2), krembi (V3) dan umur panen 7-8 bulan (U1), 8-9 bulan (U2)

*)Keterangan: notasi yang berbeda menunjukkan adanya beda nyata pada $\alpha=5 \%$

Kadar Amilosa dan Amilopektin Ubi Kayu Manis

Hasil uji lanjut Duncan dengan taraf 5\% menunjukkan interaksi antara varietas ubi kayu dan umur panen terhadap kadar amilosa dan amilopektin berbeda nyata (Gambar 4 dan 5). Ubi kayu mentega memiliki kadar amilosa yang lebih tinggi dibandingkan dengan ubi kayu manalagi dan krembi. Hal ini diduga genetik pada ubi kayu mentega dalam pembentukan molekul amilosa lebih cepat dibandingkan manalagi dan krembi. Ubi kayu yang dipanen umur 8-9 bulan memiliki kadar amilosa yang lebih tinggi yaitu 9,25\% basis kering (nilai ini adalah rata-rata 4 kali pengukuran dari ketiga varietas ubi kayu umur panen 8-9 bulan). Umur panen 7-8 bulan memiliki kadar amilosa sebesar 7,79\% basis kering (nilai rata rata 4 kali pengukuran amilosa ketiga varietas ubi kayu umur panen 7-8 bulan). Hal ini diduga dengan bertambahnya umur panen maka pembentukan granula pati dengan rantai $\alpha$ 1,4 D glikosida dengan rantai linier yang panjang lebih dominan dibandingkan dengan rantai $\alpha-1,4 \mathrm{D}$ glikosida dengan cabang $\alpha-1,6 \mathrm{D}$ glikosida. Hal ini juga diduga pada usia panen 8-9 bulan ativitas enzim starch-branching enzyme (EC: 2.4.1.18) lebih tinggi dibandingkan usia 78 bulan. Hal ini sesuai dengan penelitin Vandeputte et al. (2003); Mitsui et al. (2010) dan Bull et al. (2018) yang menyatakan bahwa pada awal pembentukan pati, amilopektin lebih dominan sedangkan ke arah penuaan maka sintesis amilosa yang lebih dominan.

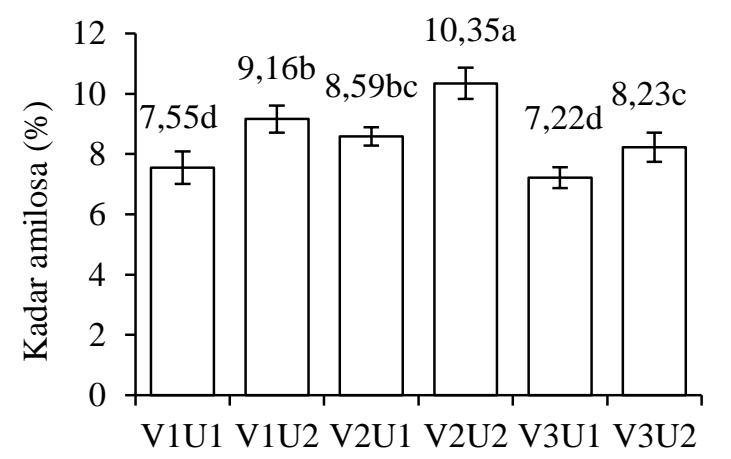

Varietas ubi kayu dan umur panen

Gambar 4. Kadar amilosa berdasarkan varietas ubi kayu yaitu manalagi (V1), mentega (V2), krembi (V3) dan umur panen 7-8 bulan (U1), 8-9 bulan (U2)

*)Keterangan: notasi yang berbeda menunjukkan adanya beda nyata pada $\alpha=5 \%$

Kadar amilosa dapat dipengaruhi oleh varietas dari ubi kayu dan umur panen. Kadar amilosa tertinggi terdapat pada ubi kayu mentega umur panen 8-9 bulan sebesar 10,35\%. Kadar amilosa yang dihasilkan dari ubi kayu mentega, manalagi, dan krembi pada umur panen 7-9 bulan di Kecamatan Palas termasuk dalam kategori rendah (Gambar 4). Menurut Triwitono et al. (2017), kategori kadar amilosa rendah 10-20\%, 20-25\% dikategorikan sedang, dan 25-30\% dikategorikan tinggi. Menurut Krogars (2003), amilosa sebagai penyusun pati yang memiliki persentase sebesar 15-30\%, sedangkan hasil analisis kadar amilosa tertinggi hanya sebesar $10,35 \%$. Tinggi rendahnya kadar amilosa disebabkan oleh keaktifan enzim de-branching dalam mensintesis amilosa. Semakin panjang rantai $\alpha-1,4$ D-glikosida yang terkandung 
pada pati maka semakin tinggi kadar amilosa di dalamnya (Vandeputte et al., 2003).

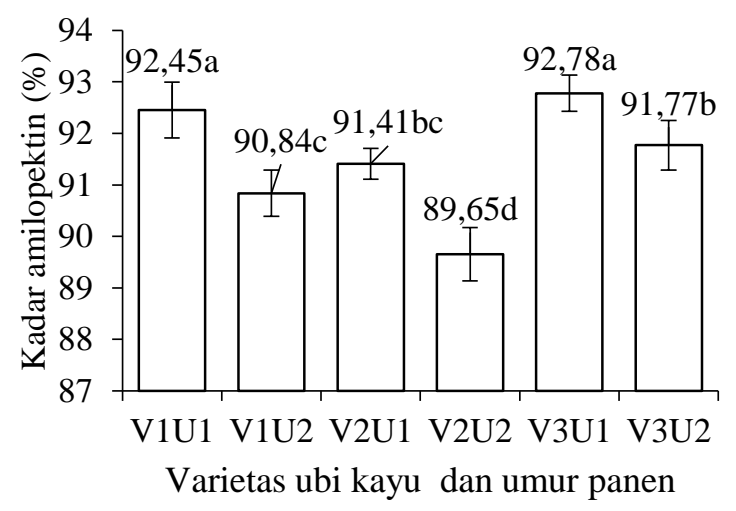

Gambar 5. Kadar amilopektin berdasarkan varietas ubi kayu yaitu manalagi (V1), mentega (V2), krembi (V3) dan umur panen 7-8 bulan (U1), 8-9 bulan (U2)

*)Keterangan: notasi yang berbeda menunjukkan adanya beda nyata pada $\alpha=5 \%$

Gambar 5 menunjukkan bahwa kandungan amilopektin dipengaruhi oleh interaksi antara umur panen dan varietas ubi kayu. Kadar amilopektin tertinggi yaitu ubi kayu varietas krembi yang dipanen pada umur 7-8 bulan sebesar $92,78 \%$ (bk), akan tetapi nilai ini tidak berbeda nyata dengan varietas manalagi yang dipanen pada umur 7-8 bulan sebesar $92,45 \%$ (bk). Kandungan amilopektin terendah terdapat pada ubi kayu varietas mentega umur panen 8-9 bulan sebesar $89,65 \%$ (bk). Tinggi rendahnya rasio amilosa dan amilopektin di dalam pati berpengaruh penting dalam aplikasi produk yang dihasilkan. Pati dengan kandungan amilosa tinggi memiliki kemampuan menyerap air dan mengembang lebih besar karena amilosa memiliki kemampuan membentuk ikatan hidrogen yang lebih besar daripada amilopektin. Ubi kayu dengan kandungan amilosa lebih rendah lebih cocok untuk digunakan pada produk yang tidak menghendaki sineresis maupun retrogradasi selama penyimpanan. Toae et al. (2019) menyatakan bahwa gel pati ubi kayu yang bebas amilosa tidak mengalami sineresis setelah penyimpanan dan freeze- thaw berulang selama 4 minggu. Nurdjanah et al. (2020) melaporkan bahwa tepung ubi kayu rendah amilosa varietas mentega menghasilkan produk kelanting yang sangat renyah. Menurut Hartati \& Prana (2003), pati dengan kadar amilosa tinggi banyak digunakan untuk berbagai produk seperti pada biodegradable film yang berfungsi sebagai substrat enzim maupun sebagai pengikat dalam pembuatan tablet, sedangkan pati free amylose sangat diperlukan untuk bahan baku makanan bayi dan kertas film dan baik digunaan untuk pembuat roti dan kue.

Pati alami memiliki kandungan amilopektin lebih banyak dibandingkan amilosa. Kadar amilopektin didapatkan dari selisih kadar pati total (100\%) dan amilosa. Ubi kayu varietas krembi memiliki kadar amilopektin yang lebih tinggi dibandingkan dengan ubi kayu manalagi dan mentega. Hal ini diduga karena setiap varietas memiliki proses metabolisme tersendiri dalam mensintesis amilopektin pada tanaman sehingga setiap varietas berbeda. Ubi kayu dengan umur panen 7-8 bulan memiliki kadar amilopektin yang lebih tinggi dibandingkan dengan umur panen 89 bulan.

Hal tersebut diduga starchbranching enzyme (EC: 2.4.1.18) dalam mensintesis amilopektin sudah optimum pada umur 7-9 bulan namun pada saat umur 8-9 bulan enzim telah mengalami kejenuhan sehingga de-branching enzyme lebih reaktif dalam mensintesis amilosa. Menurut Glicksman (1969), apabila sintesis amilopektin telah mengalami kejenuhan, maka GBSS (granule-bound starch synthase) yang terdapat pada molekul amilopektin dengan bantuan enzim debranching enzymes (EC: 3.2.1.68) akan diubah menjadi amilosa. Hal ini sesuai dengan hasil penelitian Susilawati et al. (2008) bahwa ubi kayu Kasesart memiliki kadar amilopektin pada umur panen 7 bulan sebesar $87,93 \%$ dan pada umur 9 bulan menurun menjadi $79,74 \%$. Hal ini membuktikan bahwa umur panen 
mempengaruhi rasio amilosa dan amilopektin ubi kayu.

Amilosa dan amilopektin memiliki peran yang dominan terhadap sifat fungsional pati. Sebagai contoh, suspensi pati yang dipanaskan, akan menyebabkan kedua molekul ini mengalami pembengkakan. Hal ini terjadi karena perombakan amilosa dan amilopektin menjadi butiran spherocrystalline sambil mempertahankan tingkat integritas dan identitas masing-masing. Perbedaan kandungan amilosa dengan amilopektin juga menyebabkan perbedaan sifat reologi. Ketika amilosa lepas ke dalam larutan, akan terjadi ikatan hidrogen dengan mudah sehingga akan terbentuk gel yang kaku dan buram. Sebaliknya, struktur amilopektin yang bercabang membatasi terbentuknya ikatan hidrogen sehingga larutan tetap cair dan jernih setelah pemanasan (Moore, 1984).

\section{KESIMPULAN}

Varietas ubi kayu dan umur panen ubi kayu varietas manis (manalagi, mentega dan krembi) yang ditanam di Kecamatan Palas, Lampung Selatan menghasilkan pengaruh nyata terhadap kadar air, rendemen pati, kadar pati, amilosa dan amilopektin serta terdapat interaksi yang nyata antara varietas dan umur panen terhadap kadar air, rendemen pati, dan kadar pati, namun tidak tedapat interaksi pada kadar abu, amilosa dan amilopektin. Nilai tertinggi pada kadar air terdapat pada ubi kayu manalagi umur 7-8 bulan $(67,28 \%)$, rendemen pati pada ubi kayu manalagi umur 8-9 bulan sebesar $16,34 \%$, kadar pati pada ubi kayu mentega umur 8-9 bulan sebesar $17,52 \%$, amilosa pada ubi kayu mentega umur 8-9 bulan sebesar $10,35 \%$, amilopektin pada varietas krembi umur 7-8 bulan sebesar $92,78 \%$.

\section{UCAPAN TERIMA KASIH}

Ucapan terima kasih ditujukan kepada Lembaga Penelitian dan Pengabdian kepada Masyarakat,
Universitas Lampung atas dana yang diberikan untuk melakukan penelitian ini melalui DIPA-BLU Tahun Anggaran 2019.

\section{DAFTAR PUSTAKA}

AOAC. 1984. Official Methods of Analysis. Association of Official Analytical Chemists. $14^{\text {th }}$ Edition, ArSlington.

AOAC. 2005. Official Method of Analysis. 18th Edition, Association of Official Analytical Chemists. $18^{\text {th }} \quad$ Edition, Washington DC.

Aliawati, G. 2003. Teknik analisis kadar amilosa dalam beras. Buletin Teknik Pertanian, 8 (2): 82-84.

Ayetigbo, O., Latif, S., Abass, A., and Müller, J. 2018. Comparing characteristics of root, flour and starch of biofortified yellow-flesh and white-flesh cassava variants, and sustainability considerations: A Review. Sustainability, 10: 3089.

Bertoft, E. 2017. Understanding starch structure: Recent progress. Agronomy, 7 (56): 1-29.

Bull, S.E., Seung, D., Chanez, C., Mehta, D., Kuon, J.E., Truernit, E., Hochmuth, A., Zurkirchen, I., Zeeman, S.C., Gruissem, W., and Vanderschuren, H. 2018. Accelerated ex situ breeding of GBSSand PTST1-edited cassava for modified starch. Sci. Adv., 4: 1-12.

Chairu dan Sofnie, M. 2006. Isolasi Glukomanan dari dua jenis araceae: Talas (Colacasia esculenta L.) dan ilesiles (Amorphophallus campanulatus Blumei). J. Berita Biologi, 8 (3): 171178.

Copeland, L., Jaroslav, B., Hayfa, S., and Mary, C.T. 2009. From and functionality of starch. Food Hydrocoll., 23: 1527-1534.

Dinas Tanaman Pangan, Hortikultura, dan Perkebunan Kabupaten Lampung Selatan. 2017. Angka Tetap Kabupaten Lampung Selatan Tahun 2017. Lampung. $32 \mathrm{hlm}$. 
DuBois M., Gilles, K.A., Hamilton, J.K., Rebers, P.A., and Smith, F. 1956. Colorimetric method for determination of sugars and related substances. Analytical Chemistry, 28 (3): 350-356.

Ginting, E. 2002. Teknologi penanganan pascapanen dan pengolahan ubi kayu menjadi produk antara untuk mendukung agroindustri. Bul., Palawija, 4: 67-83.

Glicksman, M. 1969. Gum Technology in the Food Industry. Academic Press, New York.

Hidayat, B., Kalsum, N., dan Surfiana. 2009. Karakterisasi tepung ubi kayu modifikasi yang diproses menggunakan metode pragelatinisasi parsial. Jurnal Teknologi Industri dan Hasil Pertanian, 14 (2): 148-159.

Hartati, N.S., dan Prana, T.K. 2003. Analisis kadar pati dan serat kasar tepung beberapa kultivar talas (Colocasia esculenta L. Schott). Jurnal Natur Indonesia, 6 (1): 29-33.

Krogars, K. 2003. “Aqueous Based Amylose Rich Maize Starch Solution and Dispersion: A Study on Free Film and Coatings". Disertation. Faculty of Science, University of Helsinki, Helsinki. pp 70.

Laya, A., and Koubala, B. 2020. Polyphenols in cassava leaves (Manihot esculenta Crantz) and their stability in antioxidant potential after in vitro gastrointestinal digestion. Heliyon, 6 (3): e03567.

Li, Y., Zhao, J., Wu, S., Fan, X., Luo, X., and Chen, B. 2016. Characters related to higher starch accumulation in cassava storage roots. Scientific Reports, 6 (19823): 1-17. (doi: 10.1038/srep19823).

Mitsui,T., Itoh, K., Hori, H., and Ito, H. 2010. Biosynthesis and degradation of starch. Bull. Facul. Agrich. Niigata Univ., 62 (2): 49-73.

Moore, C.O. 1984. Application of starches in foods. In Whistler, R. L., BeMiller, J. N., Paschall, E. F (Ed) Starch Chemistry and Technology. Academic Press, New York, pp: 575-590.
Moorthy, S.N. 2002. Physicochemical and functional properties of tropical tuber starches: A Review. Starch - Starke, 54 (12): 559-592.

Nugraha, H., Suryanto, A., dan Nugroho, A. 2015. Kajian potensi produktivitas ubi kayu (Manihot esculenta Crantz) di Kabupaten Pati. Jurnal Produksi Tanaman, 3 (8): 673-682.

Nurdjanah, S., Susilawati, dan Maya, R.S. 2008. Prediksi kadar pati ubi kayu (Manihot esculenta) pada berbagai umur panen menggunakan penetrometer. Jurnal Teknologi dan Industri Hasil Pertanian, 12 (2): 65-73.

Nurdjanah, S., Susilawati, Nawansih, O., dan Nurbaiti. 2020. Physico-chemical and sensory properties of kelanting made from high quality cassava flour. International Coference of Sustainable Agriculture and Biosystem 2019. IOP Conf. Series: Earth and Environmental Science, 515 (2020) 012066.

Nurhasan dan Pramudyanto. 1996. Buku Panduan Teknologi Pengendalian Dampak Lingkungan Industri Tapioka di Indonesia. Bapedal.

Nwokocha, C.R., Owu D.U., McLaren M., Murray J., Delgoda R., Thaxter K., McCalla G., and Young, L. 2012. Possible mechanisms of action of the aqueous extract of Artocarpus altilis (bread fruit) leaves in producing hypotension in normotensive SpragueDawley Rats. Pharmaceutical Biology, 50 (9): 1096-1102.

Prabawati, S. 2011. Manfaat Singkong. Balai Besar Penelitian dan Pengembangan Pascapanen Pertanian Bogor, Jawa Barat.

Roja, A. 2009. Ubi Kayu: Varietas dan Teknologi Budidaya. Balai Pengkajian Teknologi Pertanian Sumatera Barat, Padang.

Rubatzky, V.E., and Yamaguchi, M. 1998. Sayuran Dunia; Prinsip. Produksi dan Gizi Jilid 1. Institut Teknologi Bandung, Bandung. pp 163-177. 
Rukmana. 1997. Ubi Jalar-Budidaya dan Pasca Panen. Kanisius, Yogyakarta.

Sinar Tani. 2020. Ubi Kayu yang Hasilkan 102 Ton Ha, Cocok untuk Pangan Alternatif Saat Pandemi Covied 19. Edisi 4 Juni 2020.

Soetanto. 2001. Pengolahan Singkong. Balai Pustaka dan Media Wiyata, Jakarta.

Susilawati, Nurdjanah, S., dan Putri, S. 2008. Karakteristik sifat fisik dan kimia ubi Kayu (Manihot esculenta) berdasarkan lokasi penanaman dan umur panen berbeda. Jurnal Teknologi Industri dan Hasil Pertanian, 13 (2): 59-72.

Syamsir, E., Hariyadi, P., Fardiaz, D., Andarwulan, N. dan Kusnandar, F. 2011. Karakteristik tapioka dari lima varietas ubi kayu (Manihot utilisima Crantz) asal Lampung. Jurnal Agriteknologi, 5 (1): 93-105.

Toae, R., Sriroth, K., Rojanaridpiched, C., Vichukit, V., Chotineeranat, S., Wansuksri, R., Chatakanonda, P. and Piyachomkwan, K. 2019. Outstanding characteristics of Thai non-GM bred waxy cassava starches compared with normal cassava starch, waxy cereal starches and stabilized cassava starches. Plants (Basel, Switzerland), 8 (11). doi: 10.3390/plants8110447

Triwitono, Marsono, P.Y., Murdiati, A., dan Marseno, W. 2017. Isolasi dan karakterisasi sifat pati kacang hijau (Vigna radiata L.) beberapa varietas lokal Indonesia. Agritech, 37 (2): 192198.

Vandeputte, G.E., Vermeylena, R., Geeromsb, J., and Delcoura, J.A. 2003. Rice starches. I. Structural aspects provide insight into crystallinity characteristics and gelatinisation behaviour of granular starch. Journal of Cereal Science, 38 (1): 43-52.

Wang, L., Xie, B., Shi, J., Xue, S., Deng, Q., Wei, Y. and Tian, B. 2010. Physicochemical properties and structure of starches from Chinese rice cultivars. Food Hydrocoll., 24 (2-3): 208-216.
Yuningsih. 2009. Perlakuan penurunan kandungan sianida ubi kayu untuk pakan ternak. Penelitian Pertanian Tanaman Pangan, 28 (1): 58-61. 